\section{9}

0

1

SUPPORTING INFORMATION

\title{
Life Cycle Perspectives on Aquatic Ecotoxicity of Common Ionic Liquids
}

\author{
Amirhossein Mehrkesh and Arunprakash T. Karunanithi ${ }^{*}$
}

Center for Sustainable Infrastructure Systems, University of Colorado Denver

1200 Larimer Street, NC 2008B, Denver, Colorado, 80217

The supporting information section contains:

Section 1: The calculation procedure adopted for assembling the ionic liquid production inventory (Page S2)

Figure S1: System boundary of the study (Page S6)

Figure S2: A schematic of chemical process simulation for Production of $[\mathrm{Bmim}]^{+}[\mathrm{Br}]^{-}$(Page S7)

Figure S3: Energy and material requirements for the production of $[\mathrm{Bmim}]^{+}[\mathrm{Br}]^{-}$(Page S8)

Table S1: Consolidated energy and material requirements for production of ILs (Page S9)

Table S2: Data Sources (Page S10)

Table S3: Freshwater ecotoxicty Characterization Factors (CFs) of ionic liquids and conventional chemicals (Page S11)

Table S4: Ecotoxicity impacts related to different HCL production processes (Page S12) 


\section{Section 1}

\section{Life Cycle Inventory of Ionic Liquid Production}

27 The life cycle material and energy consumption data related to the production of the five lonic Liquids (ILs) were derived from a combination of mass and energy balances from literature, theoretical calculations, and chemical process simulation. The methodology adopted to derive this data is presented in this section. In addition, detailed material and energy flows for $[\mathrm{Bmim}]^{+}[\mathrm{Br}]^{-}$is presented in Figure S3, while a more consolidated list of material and energy requirements related to the production of other four ILS is presented in Table S1. Data sources used to translate material and energy inputs into environmental emissions are listed in Table S2.

$[\mathrm{Bmim}]^{+}[\mathrm{Br}]^{-}$: Chemical reaction and separation steps involved in the final synthesis of $[\mathrm{Bmim}]^{+}[\mathrm{Br}]^{-}$using the reactants bromobutane and 1-methyl-imidazolium was modeled using Aspen Plus software. A schematic of the process is shown in Figure S2. Kinetics data needed to model the chemical reaction step was derived from Hu et al. ${ }^{27}$ This experimental study used a micro-channel reaction system consisting of a micro-mixer and a tubular reactor to investigate the kinetics of the butylation of 1-methyl-imidazolium (MIM) towards the synthesis

$\mathrm{BrBu}+\mathrm{MIM} \rightarrow[\mathrm{Bmim}]^{+}[\mathrm{Br}]^{-}$

Our simulation included a micro-channel reactor with three tubes with an inner diameter of 1.8

$47 \mathrm{~mm}$ and length of $1.13 \mathrm{~m}$ as specified in the experimental work by Hu et al. $^{27}$ The residence time was 25 minutes. The molar flow rates of the reactants 1-bromobutane and 1methylimidazole were set at $0.1 \mathrm{~mol} / \mathrm{hr}$ and $0.08 \mathrm{~mol} / \mathrm{hr}$ respectively. The reactants entered the reactor at $80^{\circ} \mathrm{C}$ and 1 bar. The butylation process is an endothermic reaction and the reactor was simulated as an adiabatic reactor. The simulation results showed that the output flows were at $33^{\circ} \mathrm{C}$ and a conversion of $56 \%$ was achieved. The products were separated in a 
53 flash drum operating at $262^{\circ} \mathrm{C}$ and 0.5 bar, and the unreacted 1-bromobutane and 1methylimidazole were removed from the main product. The bottom product of the flash drum was enriched with ionic liquid having a purity of about $98 \%$. The thermal energy needed for the separation step (flash drum) and for pre-heating the reactants was assumed to be provided by natural gas combusted in an industrial boiler. Electricity from grid was used for compression of gases, pumping the liquids, and cooling energy requirements. The energy and materials required to produce $1 \mathrm{~kg}$ of $[\mathrm{Bmim}]^{+}[\mathrm{Br}]^{-}$(based on the simulation results) are listed in the last block of Figure S3. Inventory for the production of the reactant methyl imidazolium (MIM) was not available in any standard LCl database and therefore mass and energy needed was obtained

$\mathrm{HBr}+\mathrm{C}_{4} \mathrm{H}_{9} \mathrm{OH} \rightarrow \mathrm{C}_{4} \mathrm{H}_{9} \mathrm{Br}+\mathrm{H}_{2} \mathrm{O}$

This reaction has the same stoichiometry and is similar to chlorobutane production except that hydrogen bromide is used as the reactant instead of hydrogen chloride. Inventory data for $\mathrm{HBr}$ was also not available in $\mathrm{LCl}$ databases. Hence, life cycle inventory of $\mathrm{HCl}$ (hydrogen chloride) was adjusted and used since both reactions have the same stoichiometry and uses same process of production. The thermal and electrical energy needed to produce 1-chlorobutane chlorobenzene in the $\mathrm{LCl}$ of $\mathrm{HCl}$ was replaced with equivalent amount of bromobenzene (same molar amount). Note that $>95 \%$ of ecotoxicity impacts of the $\mathrm{HCl}$ production process is due to chlorobenzene release and substitution of it with equivalent amount of bromobenzene is a critical adjustment. Inventory data related to $n$-butanol was derived from Ecoinvent while data for other precursor materials (formaldehyde, Hydrobromic acid, ethylene glycol, ammonia, 
82 methanol, N \& P fertilizers, and lime) were gathered from Ecoinvent or USLCl database (See

83 Table S2). Whenever we had to use Ecoinvent data for chemicals derived from European

84 databases we made a critical change of adjusting the energy mix to U.S. data (we refer to this as

85 Ecoinvent adjusted to US). The energy and material data for the production of ionic liquid

$86[\mathrm{Bmim}]^{+}[\mathrm{Br}]^{-}$, are listed in Figure S3.

$87\left[\mathrm{Bmim}^{+}[\mathrm{Cl}]^{-}\right.$: Life cycle inventory for $[\mathrm{Bmim}]^{+}[\mathrm{Cl}]^{-}$production was derived from $\mathrm{CPS}$ mass and 88 energy balances collated from Righi et al. ${ }^{13}$ The suggested industrial process for the production 89 of $[\mathrm{Bmim}]^{+}[\mathrm{Cl}]^{-}$was a three-step batch process. ${ }^{13}$ Note that their inventory data was based on 90 European energy mix while we applied US energy mix to their energy data to generate our 91 inventory.

$[\mathrm{Bmim}]^{+}\left[\mathrm{BF}_{4}\right]^{-}$: The ionic liquid $\left[\mathrm{Bmim}^{+}\left[\mathrm{BF}_{4}\right]^{-}\right.$can be produced through an anion exchange 94 reaction as shown below

95

$[\mathrm{Bmim}]^{+}[\mathrm{Cl}]^{-}+\mathrm{NaBF}_{4} \longrightarrow\left[\mathrm{Bmim}^{+}\left[\mathrm{BF}_{4}\right]^{-}+\mathrm{NaCl}\right.$

97

To build the $\mathrm{LCl}$ for $\left[\mathrm{Bmim}^{+}\left[\mathrm{BF}_{4}\right]^{-}\right.$production, inventory data of $\mathrm{NaBF}_{4}$ from Ecoinvent database was combined with $\mathrm{LCl}$ data of $[\mathrm{Bmim}]^{+}[\mathrm{Cl}]^{-}$discussed before. A stoicheometric calcualtion 100 based on molar mass of reactants and products was used to estimate the amount of reactants

101 needed to produce $1 \mathrm{~kg}$ of $[\mathrm{Bmim}]^{+}\left[\mathrm{BF}_{4}\right]^{-}$. As for the ion exchange reaction step (Eqn. 3a) the

102 amount of thermal and electrical energy required was assumed to be similar to that of the final reaction step of $[\mathrm{Bmim}]^{+}[\mathrm{Cl}]^{-}$production.

104

105

$[\mathrm{Bmim}]^{+}\left[\mathrm{PF}_{6}\right]^{-}$: The same approach was utilized to derive the $\mathrm{LCl}$ for production of $[\mathrm{Bmim}]^{+}[$ 106 $\mathrm{PF}_{6}$ ]. This ionic liquid was assumed to be produced through the below anion exchange reaction: 107

108

$[\mathrm{Bmim}]^{+}[\mathrm{Cl}]^{-}+\mathrm{HPF}_{6} \longrightarrow[\mathrm{Bmim}]^{+}\left[\mathrm{PF}_{6}\right]^{-}+\mathrm{HCl}$ 
110 The invnetory for $[\mathrm{Bmim}]^{+}[\mathrm{Cl}]^{-}$was from Righi et al. ${ }^{13}$ The inventory data for $\mathrm{HPF}_{6}$ was not

111 available in standard LCl databases and hence were derived thorugh theoretical estimations

112 (using heat of reaction and heat of vaporization for reaction and separation steps) of mass and 113 energy balances required to produce $\mathrm{HPF}_{6}$ through the reaction shown below:

$1 \mathrm{H}_{3} \mathrm{PO}_{4}(\mathrm{aq})+6 \mathrm{HF}(\mathrm{aq}) \longrightarrow 1 \mathrm{HPF}_{6}(\mathrm{aq})+4 \mathrm{H}_{2} \mathrm{O}(\mathrm{l})$

117 For the upstream steps, the theoretical values of energy requirement were translated into 118 industrisal scale data using conversion factors which were specifically developed for this 119 purpose. These factors were derived by comparing the indutrial scale energy consumption of 120 producing several common chemicals with their corresponding theoritcal energy requirements. 121 In the final step of reaction tree, Eqn. 4a, the thermal and electrical energy required, were 122 assumed to be similar to the final step of $[\mathrm{Bmim}]^{+}[\mathrm{Cl}]^{-}$production.

$[\mathrm{BPy}]^{+}[\mathrm{Cl}]^{-}$: The ionic liquid $[\mathrm{BPy}]^{+}[\mathrm{Cl}]^{-}$was assumed to be produced thorugh reaction shown in 125 Eqn. 6a.

$\mathrm{BrBu}+\mathrm{C}_{5} \mathrm{H}_{5} \mathrm{~N}$ (Pyridine) $+\mathrm{C}_{4} \mathrm{H}_{8} \mathrm{O}_{2}$ (Ethylacetate) $\longrightarrow[\mathrm{BPy}]^{+}[\mathrm{Br}]^{-}$

Life cycle inventory of the precursor materials of the ionic liquid, pyridine and ethylacetate, 130 were collected from Ecoinvent while the inventory for 1-bromobutane was assembled as 131 discussed in the section of $[\mathrm{Bmim}]^{+}[\mathrm{Br}]^{-}$production. The theoretical energy needed for the final step (Eqn. 6a) was calculated based on heat of reaction and heat of vaporization as explained in 133 the prevouis sections. The input material required to produduce $1 \mathrm{~kg}$ of the ionic liquid was 134 calculated from the stoichiometry values of the reactants and products. The actual energy 135 needed for the life cycle inventory of this ionic liquid was estimated by applying the 136 aformentioned conversion factors. 


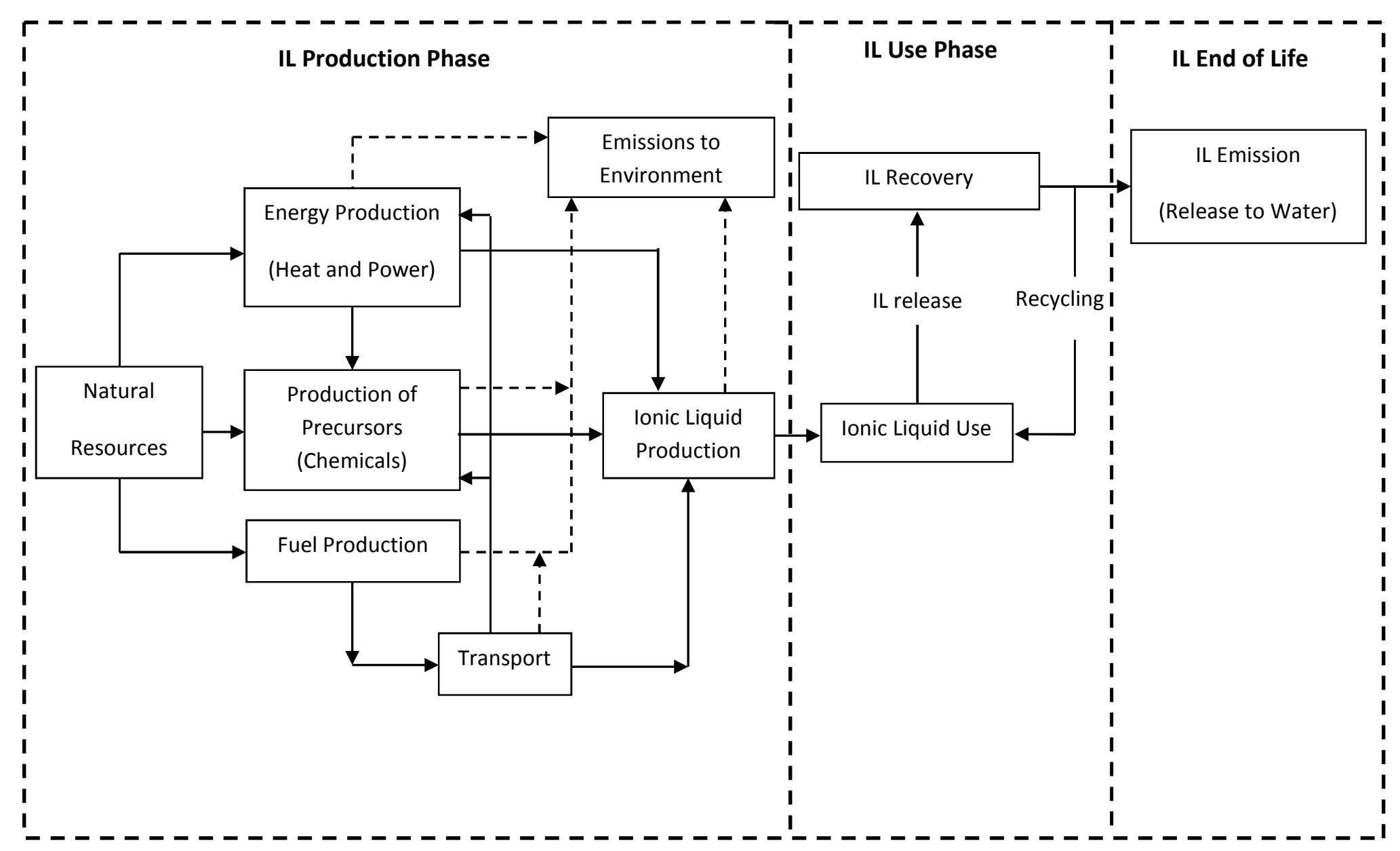

Figure S1: System boundary of the study 


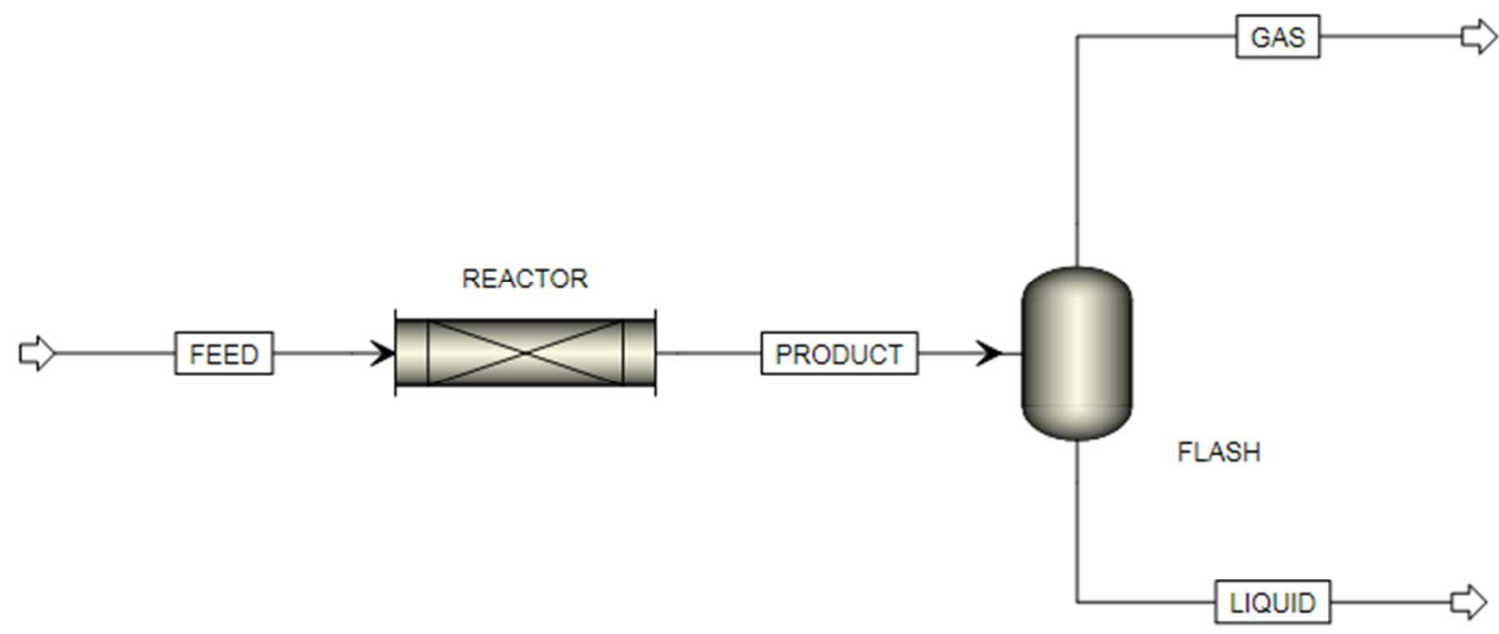

Figure S2: A schematic of chemical process simulation for Production of $[\mathrm{Bmim}]^{+}[\mathrm{Br}]^{-}$ 


\begin{tabular}{|c|c|}
\hline & 1-methylimidazole $=0.391 \mathrm{Kg}\left(\right.$ Righi et al. $\left.{ }^{13}\right)$ \\
\hline Glyoxal $=0.925 \mathrm{~kg}\left(\right.$ Righi et $\left._{\text {al. }}{ }^{13}\right)$ & Heat $=0.59 \mathrm{MJ}$ (US Industrial Boiler) \\
\hline Heat $=1.219 \mathrm{MJ}$ (US Industrial Boiler) & Electric Energy $=0.106 \mathrm{kWh}$ US grid \\
\hline Electric Energy $=0.0953 \mathrm{kWh}(\mathrm{US}$ grid $)$ & Glyoxal $=0.925 \mathrm{~kg}\left(\right.$ Righi et al. $\left.{ }^{13}\right)$ \\
\hline \multirow{3}{*}{ Ethylene glycol= $1.618 \mathrm{~kg}$ (USLCI) } & Methylamine $=0.199 \mathrm{~kg}$ (Ecoinvent adjusted to US $)$ \\
\hline & Formaldehyde $=0.518 \mathrm{~kg}$ (Ecoinvent $)$ \\
\hline & Ammonia $=0.112 \mathrm{~kg}($ USLCI $)$ \\
\hline
\end{tabular}

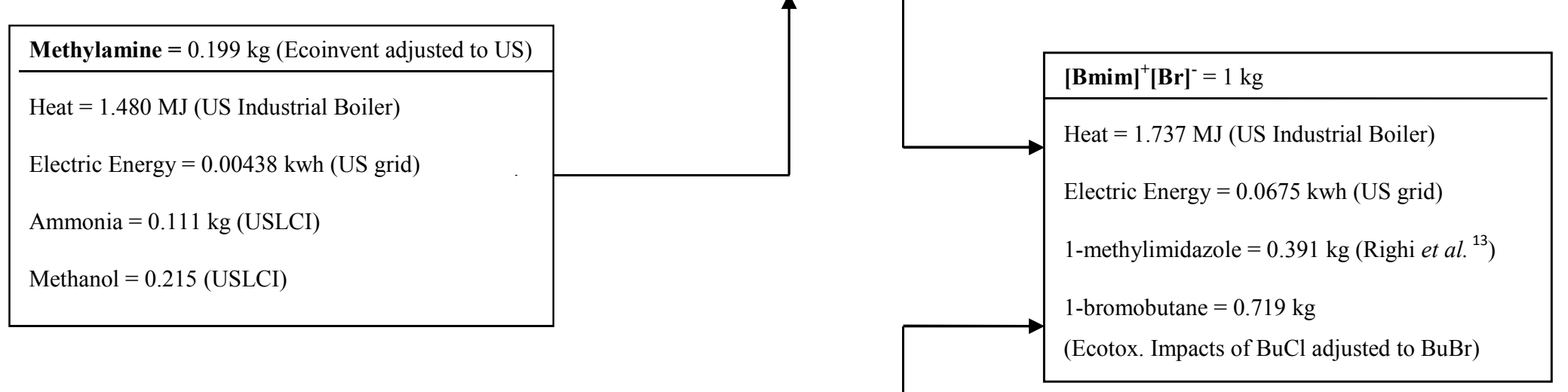

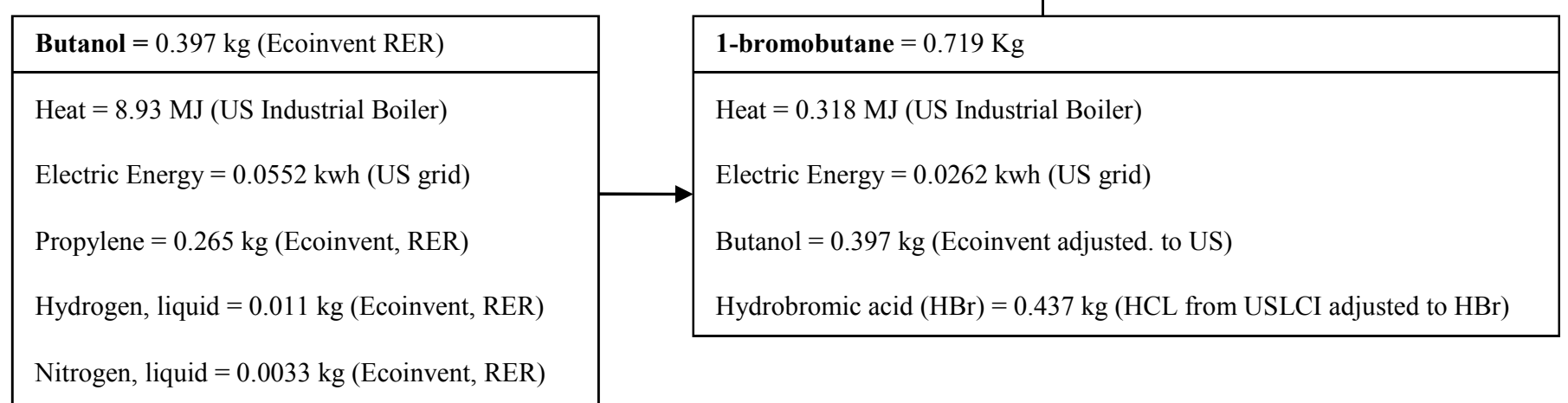

Figure S3: Energy and material requirements for the production of $[\mathrm{Bmim}]^{+}[\mathrm{Br}]^{-}$. All values are adjusted to $1 \mathrm{~kg}$ of final product $\left([\mathrm{Bmim}]^{+}[\mathrm{Br}]^{-}\right)$ 
Table S1: Consolidated energy and material requirements for production of ILS

\begin{tabular}{|c|c|c|c|}
\hline \multirow{2}{*}{ Material (1 kg) } & \multicolumn{3}{|c|}{ Inputs } \\
\hline & Precursors & $\begin{array}{l}\text { Thermal Energy } \\
\text { (MJ) }\end{array}$ & $\begin{array}{c}\text { Electricity (Kwh) } \\
\text { (US grid) }\end{array}$ \\
\hline \multirow{3}{*}[\mathrm{Bmim}]{$^{+}[\mathrm{Cl}]^{-}$} & 1-methylimidazole $(0.49 \mathrm{~kg})$ [Righi et al. $\left.{ }^{13}\right]$ & \multirow{3}{*}{1.5} & \multirow{3}{*}{0.058} \\
\hline & 1-chlorobutane $\left(0.61 \mathrm{~kg}\right.$ ) [Righi et al. ${ }^{13}$ ] & & \\
\hline & Ethyl acetate $(0.04 \mathrm{~kg})$ [USLCI] & & \\
\hline \multirow{2}{*}[\mathrm{Bmim}]{$^{+}\left[\mathrm{BF}_{4}\right]^{-}$} & $\begin{array}{l}\text { Sodium tetrafluoroborate }\left[\mathrm{NaBF}_{4}\right](0.48 \mathrm{~kg}) \\
\text { [Ecoinvent adjusted to the US] }\end{array}$ & \multirow{2}{*}{1.49} & \multirow{2}{*}{0.062} \\
\hline & {$[\mathrm{Bmim}]^{+}[\mathrm{Cl}]^{-}(0.77 \mathrm{~kg})\left(\right.$ Righi et al. $\left.{ }^{13}\right)$} & & \\
\hline \multirow{2}{*}[\mathrm{Bmim}]{$^{+}\left[\mathrm{PF}_{6}\right]^{-}$} & $\mathrm{HPF}_{6}(0.51 \mathrm{~kg})$ [This study] & \multirow{2}{*}{1.48} & \multirow{2}{*}{0.061} \\
\hline & {$[\mathrm{Bmim}]^{+}[\mathrm{Cl}]^{-}(0.61 \mathrm{~kg})\left[\right.$ Righi et al. $\left.{ }^{13}\right]$} & & \\
\hline \multirow{2}{*}[\mathrm{BPy}]{$^{+}[\mathrm{Cl}]^{-}$} & 1-chlorobutane $(0.63 \mathrm{~kg})$ [Righi et al. ${ }^{13}$ ] & \multirow{2}{*}{2.1} & \multirow{2}{*}{0.06} \\
\hline & Pyridine $(0.36 \mathrm{~kg})$ [Ecoinvent adjusted to the US] & & \\
\hline \multirow{2}{*}{$\mathrm{HPF}_{6}$} & Phosphoric acid (0.67 kg) [Ecoinvent, RER] & \multirow{2}{*}{1.17} & \multirow{2}{*}{0.316} \\
\hline & Hydrogen fluoride $(0.82 \mathrm{~kg}$ ) [Ecoinvent, RER] & & \\
\hline
\end{tabular}


Table S2: Data sources

\begin{tabular}{|l|c|}
\hline \multicolumn{1}{|c|}{ Inventory } & Reference \\
\hline Glyoxal & Righi et al. $^{13}$ \\
\hline 1-methylimidazole & Righi et $a$. $^{13}$ \\
\hline Methylamine & Ecoinvent adjusted to US \\
\hline Butanol & Ecoinvent adjusted. to US \\
\hline Hydrobromic acid (HBr) & HCL from USLCI adjusted to HBr \\
\hline Electric Energy & US grid, 2010 \\
\hline Heat & US Industrial Boiler \\
\hline 1-bromobutane & BuCl data adjusted to BuBr \\
\hline Propylene & Ecoinvent, RER adjusted to the US \\
\hline Hydrogen, liquid & Ecoinvent, RER adjusted to the US \\
\hline Nitrogen, liquid & Ecoinvent, RER adjusted to the US \\
\hline Ammonia & \\
\hline Methanol & USLCI \\
\hline Formaldehyde & USLCI \\
\hline Ethylene glycol & Calculated and adjusted to the US \\
\hline HPF 6 & Ecoinvent adjusted to the US \\
\hline NaBF & Ecoinvent adjusted to the US \\
\hline pyridine & Ecoinvent adjusted to the US \\
\hline ethylacetate &
\end{tabular}


Table S3: Freshwater ecotoxicty Characterization Factors (CFs) of the five ionic liquids and some conventional chemicals

\begin{tabular}{|c|c|}
\hline IL & CF (CTUe/kg) \\
\hline$[\mathrm{Bmim}]^{+}[\mathrm{Br}]^{-}$ & 624.375 \\
\hline$[\mathrm{Bmim}]^{+}[\mathrm{Cl}]^{-}$ & 747.448 \\
\hline$[\mathrm{Bmim}]^{+}[\mathrm{BF} 4]^{-}$ & 823.422 \\
\hline$[\mathrm{Bmim}]^{+}[\mathrm{PF} 6]^{-}$ & 927.05 \\
\hline$[\mathrm{BPy}]^{+}[\mathrm{Cl}]^{-}$ & 1767.97 \\
\hline Formaldehyde & 297.42 \\
\hline Toluene & 55.91 \\
\hline 2,3,4,6-tetrachlorophenol & 24927.8 \\
\hline Furfural & 386.82 \\
\hline Benzyl chloride & 818.11 \\
\hline Benzylamine & 182.04 \\
\hline Imidazole & 185.92 \\
\hline 2-aminopyridine & 684.75 \\
\hline Pyrene & 885597.45 \\
\hline 2,6-diphenylpyridine & 71589.60 \\
\hline 2,4-D Butyl ester & 16378.85 \\
\hline Butanone & 12515.26 \\
\hline 2,4,6-Trinitrotoluene & 9399.86 \\
\hline
\end{tabular}


Table S4: Ecotoxicity impacts related to different $\mathrm{HCL}$ production processes

\begin{tabular}{|l|l|}
\hline Process & Ecotoxicity Impacts $\left(\mathrm{CTU}_{\mathrm{e}}\right)$ \\
\hline Benzene Chlorination / EU & 8.22 \\
\hline Reaction of propylene with chlorine $\left(36 \%\right.$ in $\left.\mathrm{H}_{2} \mathrm{O}\right) / \mathrm{EU}$ & 0.027 \\
\hline Manheim process / EU & 0.353 \\
\hline Reaction of $\mathrm{H}_{2}$ with $\mathrm{Cl}_{2}$ (chlorine) /EU & 0.553 \\
\hline
\end{tabular}

